
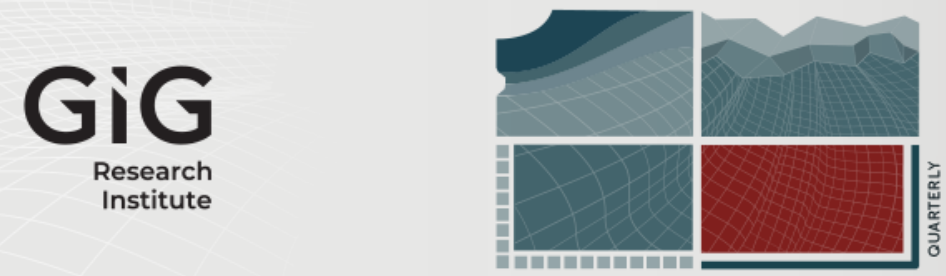

JOURNAL

OF

SUSTAINABLE

MINING

\title{
Improvement of the effectiveness of greywacke crushing process by applying an impact crusher in quarry for the production of
} railway ballast

Author(s) ORCID Identifier:

Krzysztof Kurus (iD) 0000-0002-5336-6095

Karolina Jąderko-Skubis (iD) 0000-0002-7861-1173

Follow this and additional works at: https://jsm.gig.eu/journal-of-sustainable-mining

Part of the Environmental Engineering Commons, Industrial Engineering Commons, Mining Engineering Commons, Other Environmental Sciences Commons, Other Operations Research, Systems Engineering and Industrial Engineering Commons, and the Sustainability Commons

\section{Recommended Citation}

Kurus, Krzysztof and Jąderko-Skubis, Karolina (2020) "Improvement of the effectiveness of greywacke crushing process by applying an impact crusher in quarry for the production of railway ballast," Journal of Sustainable Mining: Vol. 19 : Iss. 3 , Article 5.

Available at: https://doi.org/10.46873/2300-3960.1017

This Communication is brought to you for free and open access by Journal of Sustainable Mining. It has been accepted for inclusion in Journal of Sustainable Mining by an authorized editor of Journal of Sustainable Mining. 


\title{
Improvement of the effectiveness of greywacke crushing process by applying an impact crusher in quarry for the production of railway ballast
}

\begin{abstract}
The production of aggregates in rock mining requires an optimal system of crushers, separators and conveyors. Proper machine selection allows to obtain aggregates with appropriate technical parameters and increase the output of required fractions with a given unit cost. The usage of rock raw materials for the production of railway ballast used in the railway track superstructure is connected with the necessity to meet strictly defined quality requirements.

This paper presents an example of the use of an impact crusher in a selected quarry for the purpose of obtaining the correct parameters of railway ballast and a suitable grain curve. The evaluation was carried out on the results of technological tests, which were compared with the technologies used so far, thus ensuring the effectiveness of the solution in the practice of quarries.
\end{abstract}

\section{Keywords}

greywacke, crusher, railway ballast, aggregates, quarry

\section{Creative Commons License}

\section{(c) (i)}

This work is licensed under a Creative Commons Attribution 4.0 License. 


\title{
Improvement of the effectiveness of the greywacke crushing process by applying an impact crusher in a quarry for the production of railway ballast
}

\author{
Krzysztof Kurus ${ }^{a, *}$, Karolina Jąderko-Skubis ${ }^{b}$ \\ ${ }^{a}$ WSB University (Akademia WSB) Str. Cieplaka 1c, 41-300 Dąbrowa Górnicza, Poland

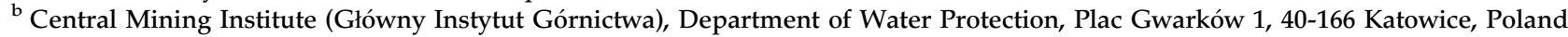

\begin{abstract}
The production of aggregates in rock mining requires an optimal system of crushers, separators and conveyors. Proper machine selection allows aggregates with appropriate technical parameters to be obtained and increases the output of the required fractions with a given unit cost. The usage of rock raw materials for the production of railway ballasts used in a railway track superstructure is connected with the necessity of meeting strictly defined quality requirements. This paper presents an example of the use of an impact crusher in a selected quarry for the purpose of obtaining the correct parameters of railway ballast and a suitable grain curve. The evaluation was carried out based on the results of technological tests which were compared with the technologies used to date, thus ensuring the effectiveness of the solution in the practice of quarries.
\end{abstract}

Keywords: greywacke, crusher, railway ballast, aggregates, quarry

\section{Introduction}

$\mathrm{T}$ he construction and maintenance of railways require a significant amount of aggregates. Yearly production of railway aggregates in Poland has reached yearly production of ca. $22 \mathrm{mln} \mathrm{Mg}$ (in quarries over $0.5 \mathrm{mln} \mathrm{Mg}$ ) [1]. Railway ballast beds mostly consist of coarse fraction 32/63 (32-50) mm made of resistant rocks. Depending on the railway category and the maximum train speed, different levels of parameters are required. In the case of high-speed main lines only natural rock is permissible as a resource to produce ballast [2]. According to Standard EN 13450 "Aggregates for railway ballast", flatness index, shape index and proper sieve curve are among the most important parameters of ballast $[3,4]$. This paper presents a trial of the improvement of railway ballast production in a quarry equipped with mobile processing machines and an abandoned stationary line (due to local noise and dust pollution). All of the processes must take place in an excavation. Due to the insufficient quality of greywacke ballast, it was assumed that the crushing technology can be improved by the replacement of a secondary stage cone crusher with a horizontal impact crusher. There are some arguments against the application of an impact crusher in hard stone application like the more significant distribution of fine particles than in the case of cone crushers, although shaping is outstanding in comparison with the cone crusher. Most of the research papers relate to finer concrete fractions produced by impactors like $0 / 16$ or $0 / 32$ [13]. Performance in the case of the production of coarse fraction may be completely different. Therefore, the main objective of this paper is to determine possible quality improvement according to EN 13450 for railway ballast made of greywacke. In most of the cases in

Received 12 August 2020; revised 6 October 2020; accepted 7 October 2020.

Available online 2 November 2020

* Corresponding author.

E-mail address: krzysztof.kurus@gmail.com (K. Kurus). 
Poland, igneous rocks are preferred for railway ballast applications, and sedimentary rocks traditionally are not so frequently used [5]. Due to many tests and adjustments, the flatness and poor shaping were not eliminated within cone crushing technology. The application of impact crushers during the secondary and tertiary stage in the case of hard rocks is not a standard solution because of the high operational cost (wear and consumables) [6]. Major benefits of the implementation of impact crushers are predictability, output and the shaping of material [7]. A preliminary experiment was carried out to compare the quality of railway ballast, as well as the additional $0 / 32$ fraction. Comparison of the crushing effects in real-life application gives complex information on what the benefits are of using impactors or cone crushers. In the case of ballast production, the most important factors are: fraction output, flatness and shaping. Proper design of crushing technology also leads to the reduction of the production of waste fractions [8]. The introduction of mobile crushers and screeners is more costly, but provides greater opportunities to change machines in a process $[9,10]$. Due to varying rock parameters, an experiment can enable comparison and help with the choice of a more appropriate unit for an existing production plant. In the following case, improvement of quality was the main motivator for the replacement of the crusher. The performance of other units were recognized as satisfactory.

\section{Materials and methods}

In order to achieve the main objective of this piece of work, which was to determine the possible improvement of the quality of railway ballast, the research methodology included the following elements:

- Analysis of quality standards and parameters for the aggregates used for construction of railway beds.

- Description and comparison of the crushers intended for the second stage of crushing.

- Analysis of process input parameters (local rock type and its characteristics).

- Description of the existing production process and an indication of areas that can be improved by the change of the mobile second stage crusher.

- Analysis of the parameters of the aggregates produced by 2 types of crushers according to standards and the output of fractions.

\subsection{Crushing processes}

The quarry industry's aim is to provide resources for concrete, road and other construction purposes [11]. According to local customers' needs, the plants, as well as processing facilities, are designed to produce aggregates which meet construction standards, such as Standard EN 13450 "Aggregates for

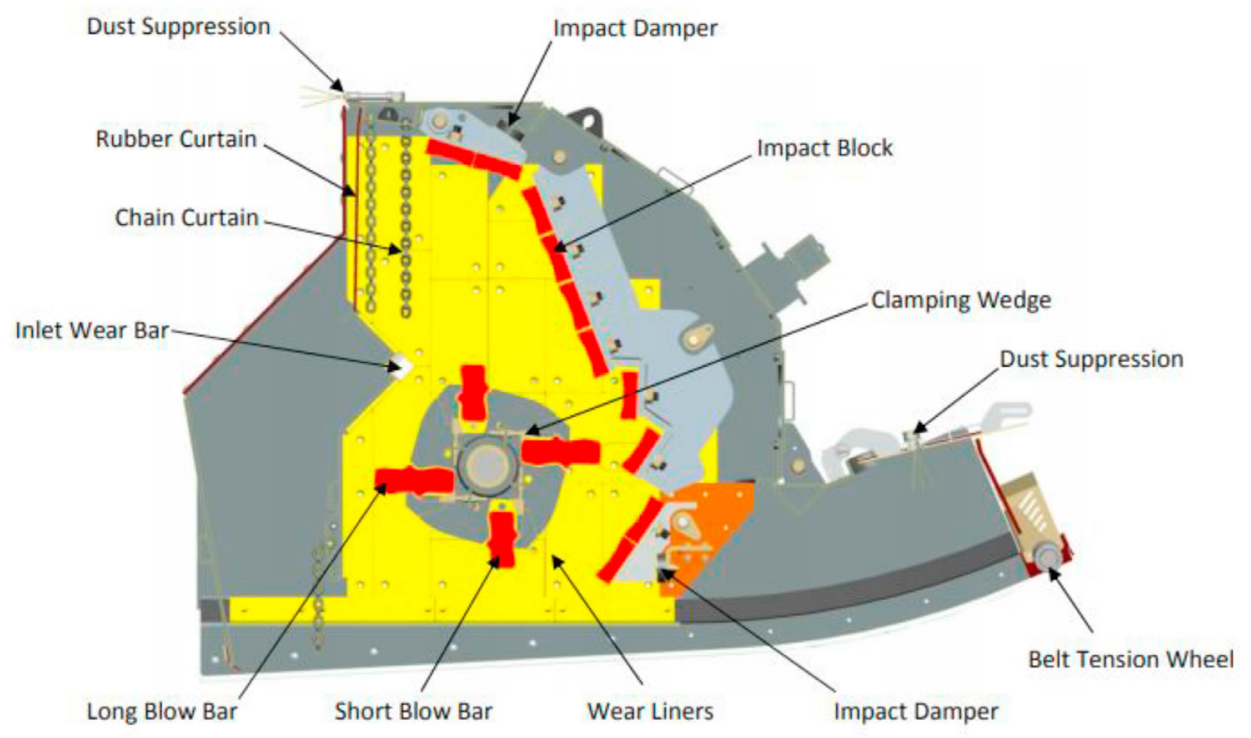

Fig. 1. Impact crusher section. Source: [12]. 
railway ballast". To maximize productivity and profit, the following factors should be considered:

- Feed parameters and input (the type of rock, curve),

- Output requirements (the quality and quantity of fractions),

- Available media, transport, and other $[9,10]$.

Railway ballasts are required to meet standards (EN 13450: Aggregates for railway ballast), especially those related to:

- Sizing fraction - proper curve as well as some oversize material,

- Physical properties (especially connected to geology and less to processing).

Shape and flatness index (in the case of main railways, the shape cannot exceed the value of 20 and a flatness value of 15).

The technology of crushing consists of the system of conveyors, screeners and crushers (in the case of mobile machines also commonly known as trains) to provide optimal product parameters. All of the plants are designed according to rock parameters and production needs. Processing plants in the quarry industry consist of a certain combination of machines like:

- A jaw crusher - simple construction, low operation cost,

- Cone crushers - relative low wear cost, good shape,

- Impact crushers - divided into HSI (horizontal shaft impactors), VSI (vertical shaft impactors), very good reduction ratio, the best shape.

The screening process is used before the operation, during and also as final classification. All of the crushing stages are sensitive to large amounts of dust and finer fraction which should be reduced before the next stage [6,9]. A typical impact crusher is presented (Fig. 1).

The principle of operation of HSI impactor is based on the very fast rotation of a rotor with mounted blow bars. Falling rocks are hit by the rotor and thrown to the impact block. Multiple impacts, rotations and mutual collisions of feed ensure good shaping and crushing ratio. In the case of very abrasive rock wear, cost can result in poor profitability or even loss. The crusher setting is a distance between the rotor and impact block [10].

Cone Crushers work by squeezing or compressing the feed between a moving steel cone and a stationary mantle. They are adjusted by the setting

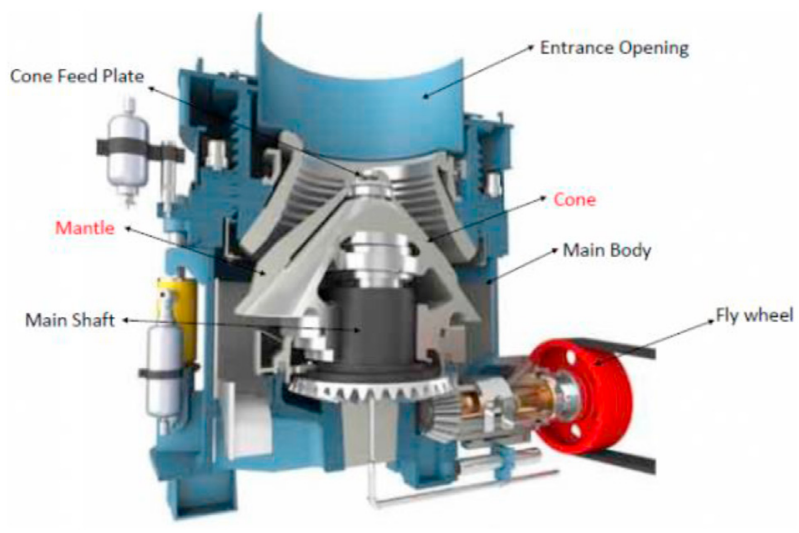

Fig. 2. Cone crusher section. Source: [13].

of the cone and mantle distance. They are the most typical secondary and tertiary crushers. The section of a cone crusher is presented in Fig. 2.

\subsection{Case study assumptions}

In the following case the aim was to ensure proper railway ballast output from a mobile crushing plant. According to local regulations, the stationary plant was closed due to a significant amount of dust and no suppression possibilities. The designed capacity was relatively low, ca. $100 \mathrm{t} / \mathrm{h}$ was viewed to be sufficient. Annual production in the plant is estimated to be ca. $200 \mathrm{k}$ tonnes. Greywacke is extracted from the deposit by blasting then thrown down from the slope. This method allows for some reduction in fraction size. As the material is being transported by the loader to a primary jaw crusher then it is transported by conveyors to the second crushing stage. The basic parameters of the rock are presented in Table 1 .

The parameters that should be taken into consideration are significant silica content as well as compressive strength. Greywacke is a sedimentary

Table 1. Greywacke, feed parameters.

\begin{tabular}{ll}
\hline Geological strata & Culm \\
\hline Colour & Dark gray \\
Texture & Layers \\
Mass density & $2691 \mathrm{~kg} / \mathrm{m} 3$ \\
Compressive strength & \\
dry & $208 \mathrm{MPa}$ \\
wet & $179 \mathrm{MPa}$ \\
frozen & $165 \mathrm{MPa}$ \\
Silica content & $45 \%$ \\
Feldspar & $15 \%$ \\
Clastic rock & $10 \%$ \\
Heavy minerals & $2 \%$ \\
Silt, clay particles & $28 \%$ \\
\hline Source: quarry documentation. &
\end{tabular}

Source: quarry documentation. 
rock with a layer structure. Its normal compressive strength varies between 170 and $210 \mathrm{MPa}$ [14]. Before the optimization there were 3 stages:

- Mobile jaw crusher, inlet ca. $1100 \mathrm{~mm} \times 700 \mathrm{~mm}$, Closed Side Setting (CSS): $80 \mathrm{~mm}$ which means the output fraction is between $0 / 140$,

- Mobile cone crusher (or stationary plant),

- Mobile final 3-deck sizing screen.

The produced fractions were $63+, 32 / 63,8 / 32$ and $0 / 8$. These fractions can be divided into others if necessary. In this case, the basic aim was to ensure 32/63 will meet railway standards. Previously the feed after it had been processed by the jaw crusher was then processed in the cone crusher. Due to its layer nature and tendency to break into "flakes", greywacke very often does not meet standards (Fig. 3). In addition and surprisingly, the output of unwanted fraction $0 / 4$ even reached as high as $30 \%$. More information is provided in the comparison of crushing technologies in section 3 .

Normally the use of impact crushers in the case of hard material is not recommended. Furthermore, relatively high silica content causes a significant wear rate. In most cases, impact crushers are used to produce high quality fractions of 0/32 or even 0/16. Mobile impact crushers are typically used for limestone, dolomite or demolition. It was decided that a close-to-reality test would be performed.

The untypical approach was justified by the following assumptions:

- The visible trend in using mobile impact crushers instead of cone units (even in the case of basalt),

- Impact crushers provide a better shape of produced aggregate,

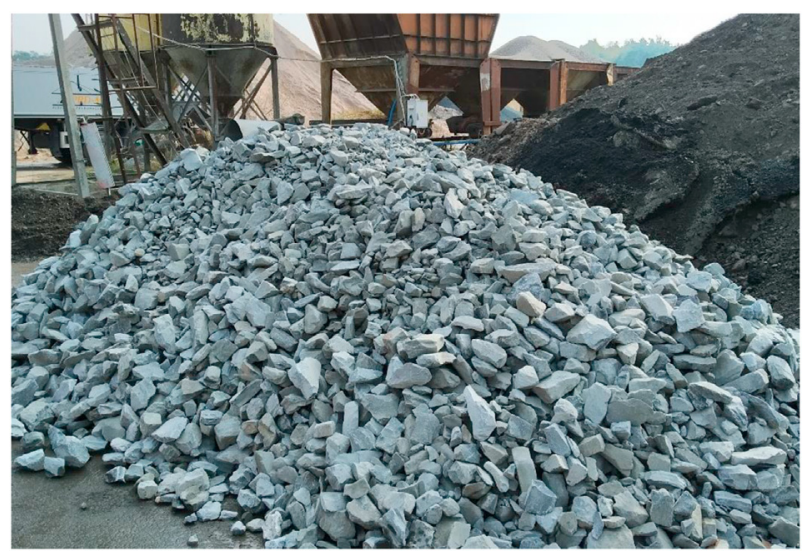

Fig. 3. Test sample of Greywacke (pic. Krzysztof Kurus).
- The designed crusher setting was much bigger than usual (ca. $65 \mathrm{~mm}$ instead of $20-30 \mathrm{~mm}$ which is normally used) - this means that the crushing ratio is relatively small at 3:1,

- The possibility to use composite ceramic blow bars (which can reduce wear cost), the easy setting of the impact crusher which does not involve the change of wears.

\section{Results and discussion}

The test was provided in order to estimate product quality after the use of an impact crusher. Based on simulation programs it was estimated that a 25 ton machine would handle the flow of $120-150 \mathrm{t} / \mathrm{h}$ of greywacke $0-300$. The machine's parameters were:

- Engine: $129 \mathrm{~kW}$, water cooled,

- $810 \times 600 \mathrm{~mm}$ chamber opening,

- 4 blow bar rotor,

- Prescreen and bypass of fine product.

In Fig. 4 an example the impact crusher is presented.

The machine is powered by a diesel engine. Material is fed by an excavator, loader or previous crusher to a hopper. Then the feed is transported by vibration to a prescreen (which reduces fines content in the feed to a chamber). Coarse material is hit by the massive blow bars on the rotor. The machine is equipped with a large screener which is located after the impact crusher. The processed material is screened to avoid an abundance of oversized material. The oversized material is again crushed in the chamber. In this case, the return system was used to screen a sample of railway ballast at $35 \mathrm{~mm}$. In the chosen machine the return conveyor can be tilted to separate a fraction, for example $+32 \mathrm{~mm}$. The test was performed at the $65 \mathrm{~mm}$ setting. The transported sample of the material mass was ca. 20 tons. The material was prescreened so that it represented

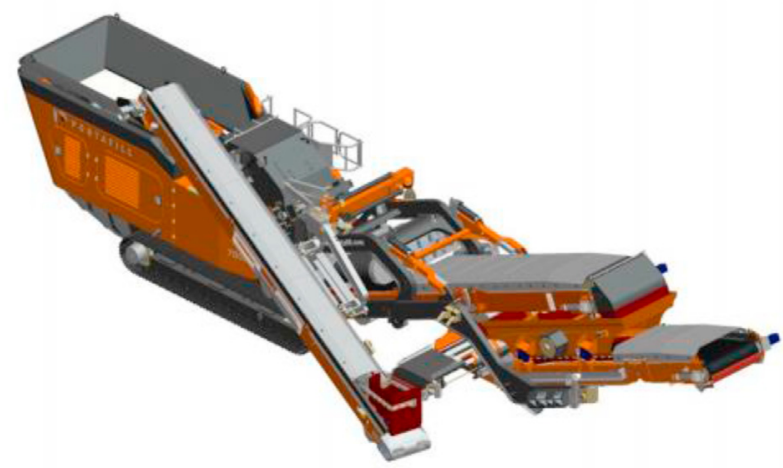

Fig. 4. Modern impact crusher with closed-loop. Source: [12]. 
Table 2. Test results, impact and cone crusher for fraction 32/63 according to Standard EN 13450 "Aggregates for railway ballast" [13].

\begin{tabular}{|c|c|c|c|c|}
\hline Crusher type & & Limit & Cone CSS $38 \mathrm{~mm}$ & Impactor CSS $65 \mathrm{~mm}$ \\
\hline Passing $90 \mathrm{~mm}$ & $\mathrm{D}$ & 100 & 100.0 & 100.0 \\
\hline Passing $80 \mathrm{~mm}$ & & 100 & 100.0 & 100.0 \\
\hline Passing $63 \mathrm{~mm}$ & & $97-99$ & 97.0 & 90.0 \\
\hline Passing $50 \mathrm{~mm}$ & & $65-99$ & 92.0 & 68.0 \\
\hline Passing $40 \mathrm{~mm}$ & & $30-65$ & 71.0 & 33.0 \\
\hline Passing $31.5 \mathrm{~mm}$ & & $1-25$ & 19.0 & 7.0 \\
\hline Passing $22.4 \mathrm{~mm}$ & & $0-3$ & 1.0 & 0.0 \\
\hline Passing $0.5 \mathrm{~mm}$ & & 0.6 & 0.0 & 0.0 \\
\hline Passing $0.063 \mathrm{~mm}$ & & 1 & 0.0 & 0.0 \\
\hline Output $31 / 63 \mathrm{~mm}$ & & $\geq 50$ & 78.0 & 83.0 \\
\hline Shape index & SI20 & $\leq 20$ & 33.0 & 26.0 \\
\hline Flatness index & Fl15 & $\leq 15$ & 21.0 & 24.0 \\
\hline
\end{tabular}

Source: Own resources.

only $32 / 300 \mathrm{~mm}$ fraction feed which is suitable in this application.

The test was divided into 2 parts. Table 2 presents the sieve analysis of potential railway fraction 32/63 acquired after the impactor test and normal cone crusher operation.

Material from the cone crusher is significantly finer, which is not desirable in the case of railway construction. The upper limit of $63+\mathrm{mm}$ was not reached by the impactor because of the lack of a screen at ca. $70 \mathrm{~mm}$. The curve shape is also better because there are fewer particles below $32 \mathrm{~mm}$. During the test, the shape index appeared to be better at the impactor. However, the flatness index was slightly worse.

Table 3 presents an additional test related to concrete fractions which are a secondary product of crushing.

In the area of quarry fraction $8 / 16$ is most valuable apart from 32/63. Its output and quality is significantly better in the case of an impact crusher. Such a result could be achieved after adding a tertiary

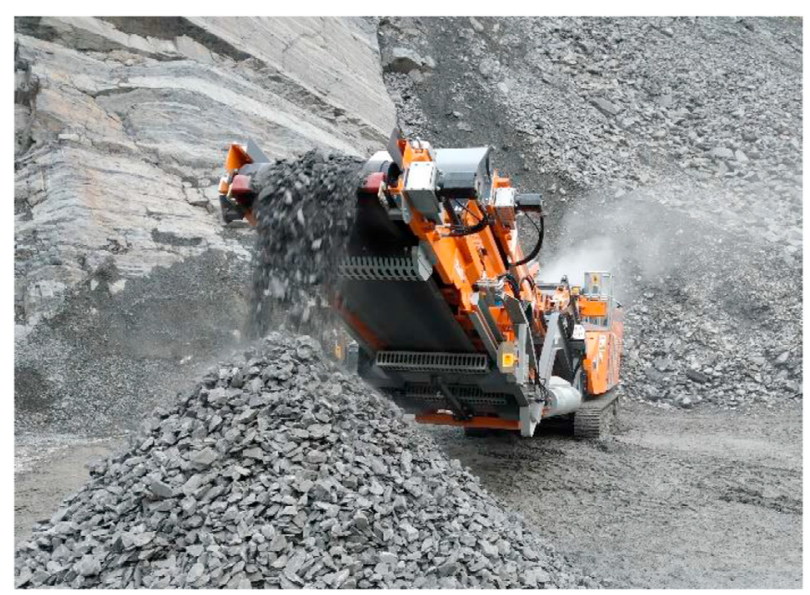

Fig. 5. Commissioning of a new mobile machine (pic. Krzysztof Kurus).
Table 3. Test results, impact and cone crusher for fraction $0 / 32$.

\begin{tabular}{lllll}
\hline Crusher type & & Limit & $\begin{array}{l}\text { Cone CSS } \\
38 \mathrm{~mm}\end{array}$ & $\begin{array}{l}\text { Impactor CSS } \\
65 \mathrm{~mm}\end{array}$ \\
\hline Passing 45 & $\%$ mass & 100.0 & 100.0 & 100.0 \\
Passing 32 & & 98.0 & 100.0 & 98.0 \\
Passing 16 & 63.0 & 70.0 & 60.0 \\
Passing 8 & & 38.0 & 45.0 & 28.0 \\
Passing 4 & 25.0 & 29.0 & 15.0 \\
Output 8/16 & $\%$ mass & 25.0 & 25.0 & 32.0 \\
Shape index 8/16 & SI & 35.0 & 44.0 & 29.0 \\
\hline
\end{tabular}

Source: Own resources.

stage of cone. What is surprising is a lower content of $0 / 4$ in the impactor product. When quarry $0 / 4$ is not washed it is a problematic product or even waste [8].

The initial cost analysis is confidential, but in relation to the cone crusher, the cost of crushing using an impactor seems to be ca. $30 \%$ higher per stage (operation). The real cost can be estimated after a few replacements of blow bars and worn parts. Other possible drawbacks of the proposed process are related to the unknown utilization cost and the lifespan of a machine working in harsh conditions. Due to the compressive strength of greywacke at $200 \mathrm{MPa}$ and its abrasiveness, and dust conditions, the machine will be exposed to fast wearing of metal covers, rubber belts as well as other components. Additionally, the impactor seems to be more capable of meeting product standards. Fig. 5 presents the commissioning of a machine chosen after testing.

\section{Conclusions}

The conducted test and other information led to the following conclusions:

- Product parameters are more optimal after the use of a mobile impact crusher instead of 
a cone unit (better shape index, curve as well as the output of valuable fractions).

- Setting adjustments is easier in the case of impact crushers (the distance between the rotor and impact block; in the case of cone crushers settings are adjusted hydraulically but the change of cone and mantles may be required for major changes in the feed fraction).

- Impact crushers may replace even 2 stages of cone crushers.

- In the case of greywacke, its tendency to break into flaky particles seems to be even more prevalent in the case of cone crusher.

- Very specific application related to the maximization of the output of $32 / 63$ and potential low wear rate related to low crushing ratio justifies the use of an impactor in the following case,

- The replacement of a cone crusher with an impact crusher is recommended.

- To improve product quality a closed-loop of oversized material was introduced. The wear rate was optimized by the application of ceramic composite blow bars.

\section{Ethical statement}

The authors state that the research was conducted according to ethical standards.

\section{Funding body}

None.

\section{Conflicts of interest}

None.

\section{References}

[1] Radwanek-Bąk B. Krajowa baza zasobowa kruszyw łamanych dla kolejnictwa. Surowce i Maszyny Budowlane 2019;1: 50-3.

[2] Warunki Techniczne Wykonania I Odbioru Podsypki Tłuczniowej Naturalnej I Recyklingu Stosowanej W Nawierzchni Kolejowej. Załącznik Do Uchwały Nr 1237/2016. Warszawa: Zarządu PKP PLK SA; 2016.

[3] Standard EN 13450. Aggregates for Railway Ballast. 2013.

[4] Bengtsson M, Evertsson C. Measuring characteristics of aggregate material from vertical shaft impact crushers. Min Eng December 2006;19(15):1479-86. https://doi.org/10.1016/ j.mineng.2006.08.003.

[5] Kozioł W. Kruszywa Dla Kolei. Nowoczesne budownictwo inżynieryjne; 2019. p. 82-6.

[6] Basics in Minerals Processing. Helsinki: Metso Corporation; 2018.

[7] Serina N, Engelsen J. Waste and Supplementary Cementitious Materials in Concrete. Woodhead Publishing Series in Civil and Structural Engineering; 2018. p. 229-55. https:// doi.org/10.1016/B978-0-08-102156-9.00008-0.

[8] Foitova P, Białecka B, Kurus K, Volgyi V. Comparison of method about use mining waste in Czech Republic and Poland1. International Multidisciplinary Scientific GeoConference: SGEM: Surveying Geology \& Mining Ecology Management; 2013. p. 317-24.

[9] Gawenda T. Comparative analysis of mobile and stationary technological sets for screening and Grinding Rocznik Ochrona Środowiska 2013. Rocznik Tom 2013;15(cz. 2): 1318-35.

[10] Gawenda T. The influence of rock raw materials comminution in various crushers and crushing stages on the quality of mineral aggregates. Gospodarka Surowcami MineralnymiMin Resour Manag 2013;29(1):53-65.

[11] Kozioł W, Baic I. Rock mining in Poland - current Status and conditions for development. J Polish Min Eng Soc 2018: 65-71. https://doi.org/10.29227/IM-2018-02-08.

[12] Portafill. Mobile Impactor Portafill 7000IC-R - Technical Brochure. 2020.

[13] Sigma Plantfinder. Retrieved from: https://www. sigmaplantfinder.com/blog/how-does-a-cone-crusher-work. [Accessed 1 August 2020].

[14] Závacký M, Majda T, Rozsypalová I, Štefaňák J. Moravian greywacke - evaluation of fracture, strength and deformability properties. In: AG 2019 - 5th International Conference on Applied Geophysics. E3S Web of Conferences; 2019. p. 1-8. https://doi.org/10.1051/e3sconf/201913302003. 